\title{
nature
}

\section{Neuroethics needed}

Researchers should speak out on claims made on behalf of their science.

| ow would you feel if you had to tell the truth, and nothing but the truth, for a day? Did your wife really look so good in that dress? Were you honestly late just because the traffic was bad? Did you actually do all the necessary controls for that experiment?

Society would be a different place if all our lies, however trivial, were abandoned in favour of blunt honesty. In some areas, such as criminal prosecution, this might be advantageous. In others, where little white lies help life run smoothly, knowing all the facts might be uncomfortable.

These thoughts are brought to the fore by the arrival of two US start-up companies, No Lie MRI and Cephos, which are about to offer functional magnetic resonance imaging (fMRI) brain scans in order to detect lies. The companies, which plan to launch their services later this year, say their goal is to help exonerate the innocent, and to replace the widely discredited polygraph machines used by US government agencies for screening their staff (see page 918).

Many neuroscientists think the claims being made for $\mathrm{fMRI}$ are overblown. They warn that there is scant evidence that it can reliably distinguish a lie from the truth in any individual case, especially in the real-life, high-stakes situations in which it might be applied.

Ethicists worry even more about what would happen if one day the scanning technique could be used to accurately discern people's inner secrets. Society would, for the first time, hold in its hands a reliable tool with which to finger deceit, and this could have a profound impact on individual privacy and human rights.

It is too early to tell if fMRI will ever be able to pinpoint liars in anything but a few, tightly controlled circumstances. Studies so far have been conducted under such conditions, and do not reflect the many types oflies and the situations they may be used to investigate. Some will argue that the mere threat of an accurate lie test could be used to extract valuable information - the same argument, in essence, that led to the use of polygraphs in the United States.

The question of how far such approaches should be taken is just one of a number of pressing ethical issues raised by the rapid recent

progress of neuroscience. So it is appropriate that last month, a group of prominent scientists, ethicists and lawyers gathered at the Asilomar conference centre in California to found the Neuroethics Society, which will address these issues.

This effort is to be applauded, but there is a lot of work to do before it can engage a rapidly expanding neuroscience community that has been relatively slow to recognize its own responsibility to address potential abuses of knowledge.

Geneticists held their own landmark Asilomar meeting more than thirty years ago to discuss the possible regulation of recombinant DNA. Today, the ethical and social repercussions of genetics are a standard component of undergraduate education. But ethics is a long way from attaining corresponding status within neuroscience. One prominent bioethicist reports that his own lecture on neuroethics was cancelled, falling victim to timetable pressure.

Neuroscientists have reasons for their reluctance to wade into ethics. The questions raised are likely to be open-ended, and their arrival in the world outside the laboratory may be some way off. Whereas a genetic test can say something definitive about a particular genetic make-up, and therefore about predisposition to disease, for example, an fMRI scan is just an indirect

"The arrival of No Lie MRI and Cephos suggests that $f M R l$ is entering the 'real world', whether neuroscientists consider it ready or not." measure of neural activity based on oxygenated blood flow. For now, neuroscientists have only the most basic grasp of what this says about how the brain processes information.

Even so, the arrival of No Lie MRI and Cephos suggests that fMRI is entering the 'real world, whether neuroscientists consider it ready or not. The community needs to broadcast its doubts about this situation from the rooftops - and prepare for a prolonged, complex and occasionally frustrating engagement with the public on the ethical ramifications of its work.

\section{Urgent but balanced}

\section{Energy problems demand a coherent solution, not a quick fix.}

7 he energy issues facing many of the world's governments are now acute. And there is a disturbing tendency for this urgency to generate polarizing debates on plans that could have only a marginal effect on the unfolding crisis. In the United States, such an argument has taken place over oil drilling in the Arctic National Wildlife Refuge. In Britain, an almighty row is looming over the replacement of a small number of ageing nuclear power stations.
The urgency of the current crisis is driven by stubbornly high oil prices, the clear need to do something about greenhouse-gas emissions, and the benign neglect that has characterized many national energy policies for the past two decades. But the crisis demands more than the flailing efforts of governments or political parties to develop headline-grabbing initiatives. It calls, instead, for a thorough, rational and rapid analysis of how effective energy policies should be rebuilt.

A report released this week by the Royal Society of Edinburgh (RSE) attempts to provide such an analysis for Scotland - a small country whose energy issues are not untypical of those facing Western Europe.

The exhaustion of North Sea oil and gas, together with the rapid 
ageing of coal and nuclear power stations, presents a challenge for the Scottish Executive and the British government in London. Under Scotland's 1999 devolutionary settlement, London sets the energy policy, but Edinburgh is responsible for implementing it.

As the RSE's report explains, the energy crisis won't be addressed either by building wind-farms on the Isle of Lewis, or by licensing replacements for the nuclear plants that now produce half of Scotland's electricity. What's needed instead is a wide diversity of approaches to electricity generation and to energy use and distribution, and a comprehensive, integrated strategy for their implementation. The report's 37 recommendations are not a cop-out from making choices, but are instead a realistic acknowledgement of the breadth of the problem.

Some of the recommendations concern such humdrum matters as making more effective use of existing planning regulations to construct energy-efficient buildings - an area in which Britain has always lagged behind its neighbours. The report also calls for a more diverse approach to renewable energy, pointing out that the Scottish Executive's existing incentive system serves to promote wind capacity (which can be built now) over alternatives such as wave power that require further research and development. And it suggests that the executive should promote research collaborations in technologies such as clean coal and wave power, in which local industrial companies and researchers have international expertise.

But the most important recommendation is perhaps the dullest: a call for an agency, outside the government but answerable to it, that will formulate, champion and implement an energy strategy. This demand is also pertinent to Britain as a whole, which shut its energy department in 1992. But it isn't at all clear whether the resources will be provided to establish such an agency.

Maxwell Irvine, the physicist who chaired the RSE panel, fears that without a comprehensive energy strategy, Britain's privately owned electricity industry will repeat the 'dash-for-gas' - the Thatcherite energy policy of the $1980 \mathrm{~s}$. That policy caused the nation to burn its irreplaceable North Sea gas supplies, rendering itself dependent, in the long term, on imported gas to keep the lights on.

The RSE committee, which raised funds for the study from foundations and other sources, is to be congratulated on bringing some sanity to an energy debate that is becoming unhinged from reality. In elections next spring, for example, the ruling coalition in the Scottish parliament looks set to split over the issue of nuclear power.

What is needed instead, in Scotland, the United Kingdom, the United States and elsewhere, is a rational energy strategy, executed by a competent agency. It is only this that can take energy usage over many years to a sustainable position, with no more lurches from complacency to crisis.

\section{The mad technologist}

\section{Hollywood warms to science, but fears technology.}

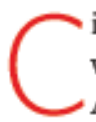

inema has been around for more than 100 years now, but the world has not tired of it. According to the Motion Picture Association of America, 9.6 billion tickets to the cinema were sold around the world in 2004. Film was, arguably, the single most important artistic medium of the twentieth century. Its resonance and power alone make it an object worthy of study.

It is also an art that technology has rendered possible. More than an opera, a play or a novel, film is a technological product, spawned directly by the inventions of electricity and celluloid. Before the Lumière brothers' cinématographe showed moving images of Lumière factory workers knocking off work for the day, the groundwork was laid by the invention of the pinhole camera and Eadweard Muybridge's motion-capturing photographs, for example.

So how does this most modern of media see science? On-screen, apart from a few earnest biopics of Louis Pasteur or the Curies, scientists are often portrayed as comically inept eccentrics or evil geniuses bent on world domination. They frequently re-enact Frankenstein-creator Mary Shelley's lesson about playing god - and are almost as frequently dispatched by their own twisted creations.

Yet scientists are less interested in creating things than in finding things out - discovering new species, rather than manufacturing them. Many 'mad scientists' on film are really engineers of one kind or another. They are technologists.

This muddling of science and technology is common, and it could be argued that scientists haven't helped things by claiming full credit for technologies - such as nuclear power or modern medicine - that they merely made possible through their discoveries. If we tease science and technology apart, we find that pure scientists are often treated kindly by film-makers, who have portrayed them sympathetically, as brooding mathematicians (A Beautiful Mind) and heroic archaeologists (Raiders of the Lost Ark).

It is technology that movie-makers seem to fear. Even the bestloved science-fiction films have a distinctly ambivalent take on it. Blade Runner features a genetic designer without empathy for his creations, who end up killing him. In 2001: A Space Odyssey, computers turn against humans, and Star Wars has us rooting for the side that relies on spiritual power over that which prefers technology, exemplified by the Death Star. Why would an inherently technological medium seem to be so wary of its own creator?

Modern technology has changed lives considerably, as becomes dear when we consider that television has been around for only about 70 years. No doubt technology has improved lives in ways that can easily be felt and measured. But it takes some getting used to. Many people find the constant introduction "Films such as Primer and Schläfer have given the world a more realistic look at scientists, albeit ones with more interesting livesthan most." of new gadgets and the faster pace of life alienating and exhausting. It may be that our first completely technological art form is the one best suited to exploring how we feel about modern life.

At any rate, the mad scientist is not the only image of science. Films such as Primer and Schläfer (see page 922) have given the world a more realistic look at scientists, albeit ones with rather more interesting lives than most. There is drama and pathos to be found in the laboratory, even without the wild hair and insatiable desire to rule the world. 